\title{
АНТИБИОТИКОРЕЗИСТЕНТНОСТЬ ВОЗБУДИТЕЛЕЙ БАКТЕРИАЛЬНЫХ ИНФЕКЦИЙ ЖИВОТНЫХ В УКРАИНЕ
}

\author{
Т. А. ГАРКАВЕНКО \\ Государственный НИИ по лабораторной диагностике и ветеринарно-санитарной экспертизе, \\ г. Киев, Украина, 03151 \\ (Поступила в редакичию 28.01.2017)
}

\begin{abstract}
Резюме. В статье описан анализ результатов исследований чувствительности возбудителей бактериальных инфекций животных в Украине к антибактериальным препаратам.

Установлено, что на территории Украины среди животных ииркулирует много резистентных бактерий к $\beta$-лактамам, макролидам, аминогликозидам, фторхинолонам, тетрачиклинам и другим группам антибиотиков.

Ключевые слова: антибиотики, резистентность, устойчивость, микроорганизмы.
\end{abstract}

Summary. The article describes the analysis of the results of the sensitivity to antibacterial drugs of animals bacterial pathogens in Ukraine.

Set that on the territory of Ukraine in animals circulates a lot of bacteria resistant to $\beta$-lactams, macrolides, aminoglycosides, fluoroquinolones, tetracyclines, and other groups of antibacterial drugs.

Key words: antibiotics, resistance, stability, microorganisms.

Введение. В настоящее время резистентность к антибактериальным препаратам представляет серьезную нарастающую международную проблему общественного здравоохранения. Из-за устойчивости к антибиотикам инфекции, которые обычно подвергались антибиотикотерапии, стало трудно или даже невозможно устранить. Неудачи в лечении приводят к увеличению заболеваемости, смертности и экономическим потерям.

Устойчивость к различным классам антибиотиков стабильно растет у различных видов бактерий, а также в различных экологических условиях.

Под угрозой находится значение антибиотиков как лекарств, спасающих жизни больным.

Анализ источников. На протяжении всего своего существования человечество было подвержено различным инфекционным заболеваниям. В течение многих лет средневековые алхимики пытались найти чудодейственные лекарства от всех болезней. Препараты, созданные на основе серебра, ртути, мышьяка отличались высокой токсичностью и низкой эффективностью. Несбыточная мечта ученых осуществилась только в XX веке, когда были открыты антибиотики - лекарственные 
вещества, обладающие способностью убивать или подавлять рост и размножение различных видов микроорганизмов [1-3].

Начиная с 40-х годов прошлого века, антимикробные препараты (АМП) активно применяются и в ветеринарии. В противоположность медицине, где индивидуальное применение антибиотиков является правилом, молодняк сельскохозяйственных животных, например, поросята и бройлерные цыплята, нередко получают антибиотики все вместе. Соответственно у таких животных контакты с антибиотиками происходят гораздо чаще, чем у людей.

После появления в 1950-х годах антибиотиков-стимуляторов роста (ACP) они были внедрены в глобальных масштабах для планового использования при промышленном разведении сельскохозяйственных животных, независимо от состояния здоровья животных или риска бактериальных инфекций. Так, в США использование антибиотиков в качестве стимуляторов в период с 1951 по 1978 возросло в 50 раз (с 110 тонн до 5580 тонн), при том что масштабы применения антибиотиков для лечения заболеваний у людей и животных увеличились только в 10 раз $[4,5]$. За это время многие штаммы бактерий, выделенных от людей и животных, ранее чувствительных к антибиотикам, стали резистентными. Аналогичная ситуация наблюдалась и в других странах. Например, в Великобритании превалентность среди домашней птицы штаммов Escherichia coli, устойчивых к тетрациклину, выросла с 3,5 \% до 63,2 \% всего лишь после четырех лет (1957-1960 гг.) применение антибиотиков в птицеводстве [6].

В Великобритании в 1968 г. был создан Объединенный комитет по применению антибиотиков в промышленном животноводстве и ветеринарии, из-за опасений возможности побочного влияния на состояние здоровья людей. Этим комитетом был разработан доклад, который положен в основу разработки политики рационального применения антибиотиков и соответствующих регламентов во многих западноевропейских странах [7].

Тем не менее глобальное применение АСР продолжалось до 1986 года, когда Швеция запретила их использование, поскольку нарастала озабоченность в связи с продолжающимся расширением устойчивости к антибиотикам. Исследователи установили, что применение антибиотиков у сельскохозяйственных животных может создавать риски для здоровья людей из-за распространения резистентности к этим препаратам через пищевую цепь, в частности, исследователи показали, что применение АСР представляет опасность для здоровья людей через формирование и распространение перекрестной устойчивости к антибиотикам, используемых для лечения людей. 
Поэтому некоторые страны прекратили регистрацию отдельных антибиотиков как стимуляторов роста: например, Дания и Норвегия в 1995 году запретили применение авопарциина, а с 1997 года было прекращено применение этого препарата в других странах ЕС.

Угроза развития антибиотикорезистетности также вызвала серьезную реакцию со стороны потребителей, о чем свидетельствуют рекомендации по рациональному применению антибиотиков, опубликованные Комитетом ЕС по экономической и социальной политике [8].

Многие страны провели оценку рисков, связанных с применением $\mathrm{ACP}$, и показали, что эти препараты представляют угрозу для здоровья людей. С 1997 года ВОЗ рассматривает проблему риска АСР для общественного здоровья и рекомендует немедленно или в ближайшее время прекратить использование АСР [8]. С 2006 года все АСР были запрещены к применению в странах ЕС на основании рекомендаций Научного рабочего комитета [9].

Устойчивые микроорганизмы могут быть переданы людям при непосредственном контакте с животными, через пищевые продукты и объекты внешней среды. Данные из стран ЕС показывают, что спектр резистентности штаммов сальмонелл, выделенных от свиней, крупного рогатого скота и цыплят, сходен со спектром устойчивости у сальмонелл, выделенных из соответствующих продуктов и от людей. В первую очередь это относится к персоналу, работающему в сельском хозяйстве. По данным ряда авторов, у людей, работающих с животными, чаще выделяют антибиотикорезистентные микроорганизмы из носовой, ротовой полости и из содержимого кишечника [10].

Цель работы - изучить ситуацию по резистентности к возбудителям бактериальных заболеваний животных к антибактериальным препаратам в Украине.

Материал и методика исследований. Материалом для исследования были собственные исследования, а также данные анализа ветеринарной статистической отчетности. Для изучения резистентности основних возбудителей бактериальных заболеваний животных использовали класический диско-диффузионный метод Кирби-Бауэра $[11,12]$. Было происследовано 789 клинических изолятов E.coli, 163 сальмонеллы, 734 стафилококка, 303 изолята стрептококков, 65 культур Pseudomonas aeruginosa, 76 пастерелл, выделенных от животных и птиц государственными лабораториями ветеринарной медицины Украины и Государственным научно-исследовательским институтом по лабораторной диагностике и ветеринарно-санитарной экспертизе в 2016 году. Интерпретацию результатов исследования проводили по методологии EUCAST [13]. При статистическом подсчете определяли 
среднее арифметическое, медиану, среднее квадратической отклонение, используя программу Exell.

Результаты исследований и их обсуждение. Бактериальными инфекциями, которые чаще всего регестрируются на територии Украины у животных и птицы, являются эшерихиозы, пастереллез, сальмонеллез, стафилококкоз, стрептококкоз, рожа, отечная болезнь свиней, псевдомоноз.

Чаще всего из патологического и биологического материала от животных и птицы в 2016 году выделяли кишечную палочку. Специалистами государственных лабораторий ветеринарной медицины Украины на чувствительность к антибактериальным препаратам было происследовано 789 изолятов E.coli, из которых 592 проявили резистентность к антибиотикам. Количество выделенных культур и резистентность микроорганизмов к антибиотикам по областям отличается. Так, в Запорожской области изолированно наибольшее количество кишечной палочки - 252 культуры, из которых 207 проявляли устойчивость к антибиотикам. Самый высокий процент устойчивости наблюдался к ß-

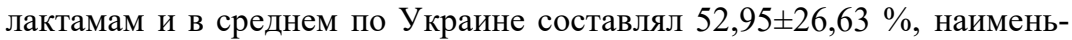
ший процент кишечных палочек, устойчивых к этой группе АБП, был получен по Луганской области и составлял 5,9 \%, в то время как E.coli, изолированные от животных из Житомирской и Киевской областей, имели 100 \% устойчивость к ß-лактамам. Также у этих микроорганизмов наблюдалась высокая резистентность к антибиотикам группы тет-

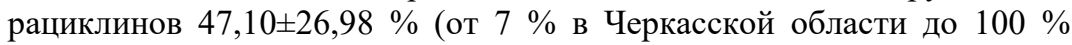
устойчивости в Киевской и Черновицкой областях). Активное применение в ветеринарии препаратов хинолонового ряда привело к появлению резистентных штаммов E.coli и в среднем этот показатель по

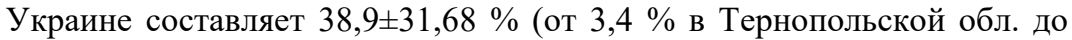
$100 \%$ устойчивости в Донецкой, Житомирской, Ивано-Франковской и Кировоградской областях). Не уступают и макролиды, аминогликозиды, к ним проявляли устойчивость 30,2 29,08 \% (от 9,1 \% по Херсонской обл. до $100 \%$ - в Николаевской и Черновицкой областях) и $34,35 \pm 25,0$ \% (от 9,1 \% по Херсонской обл. до 100 \% в Черновицкой обл.) соответственно выделенных культурр. Также были выделены изоляты E.coli, резистентные к нитрофуранам $(27,7 \pm 2,12 \%)$, полимиксинам (от $2 \%$ до 87,5 \% по разным областям), сульфаниламидам $(14,7 \pm 8,31 \%)$, карбапенемам $(21,75 \pm 2,47 \%)$.

Лидирующую позицию удерживают и стафилококки. Из 734 изолятов - 497 культур проявили резистентность к антибиотикам. Самый высокий процент устойчивости наблюдался к макролидам и в среднем по Украине составлял 52,8 $\pm 32,87$ \%, наименьший процент стафилококов, устойчивых к этой группе АБП, был получен по Днепропетров- 
ской области и составлял 4,7 \%, в то время как стафилококки, изолированные от животных из Житомирской и Луганской областей, имели $100 \%$ устойчивость к антибиотикам группы макролидов. Также у этих возбудителей наблюдалась высокая резистентность к антибиотикам группы тетрациклинов $51,5 \pm 33,62 \%$ (от $2 \%$ в Черкасской области до $100 \%$ устойчивости в Житомирской, Ивано-Франковской и Киевской областях). К аминогликозидам показатель устойчивых стафилококков колебался по Украине в пределах 50,8 22,79 \% (от 14,3 \% в Тернопольской обл. и до 100 \% в Ивано-Франковской областях). Стойкость к ß-лактамам составила $45,8 \pm 26,64 \%$ (от $4,2 \%$ по Львовской обл. до $100 \%$ - в Житомирской и Киевской областях), следует отметить, что было изолировано 46 штамов метициллинрезистентных стафилококков. Также были выделены стафилококки, резистентные к фторхинолонам (процент устойчивых культур колебался от 5,7 \% до $100 \%$ по разным областям), нитрофуранам (от 2,3 \% до 17,6 \%), полимиксинам (от $2 \%$ в Черкасской обл. до $100 \%$ в Луганской), сульфаниламидам $(14,2-19,4 \%)$, карбапенемам (20,8 \%), рифампицинам $(23,7 \pm 13,65 \%)$, линкозамидам (от 14 до $100 \%$ ).

Что касается сальмонелл, то из 163 выделенных культур, исследование которых проводилось на чувствительность к антибактериальным препаратам, 112 оказались резистентными к ним. В Хмельницкой области было зарегистрировано наибольшее количество сальмонелл (40 изолятов), которые проявили высокую $100 \%$ резистентность к антибиотикам тетрациклиновой группы, $\beta$-лактамам (полусинтетическим), макролидам, к аминогликозидам устойчивость наблюдалась у 97,5 \% испытуемых культур. К этим же группам антибактериальных препаратов в целом по Украине резистентность наблюдалась в таких пределах: $60,0 \pm 39,33 \%, 50,0 \pm 32,96 \%, 80,0 \pm 33,22$ и 52,9 $26,37 \%$ соответственно.

Возбудители стрептококковых инфекций животных также были устойчивы к антибактериальным препаратам. Из исследованных 303 изолятов стрептококков, резистентность к антибиотикам проявилась у 226. Процент устойчивых к этой группе антибиотиков штамов значительно колебался в разных областях Украины: по $\beta$-лактамам - от $3,3 \%$ до $100 \%$, к макролидам - от 4,7 \% до $100 \%$, к аминогликозидам от $17,2 \%$ до $100 \%$, к фторхинолонам - от $6,3 \%$ до $100 \%$, к тетрациклинам - от $10 \%$ до $100 \%$. Стрептококки, выделенные от животных и птицы, из Львовской и Житомирской области проявили 100 \% полирезистентность к антибактериальным препаратам группы аминогликозиды, фторхинолоны, тетрациклины, полимиксины и $\beta$-лактамамам, макролидам, фторхинолонам, тетрациклинам, плевромутелинам соответственно. 
Pseudomonas aeruginosa, выделенные бактериологами имели особенно высокую устойчивость. По $\beta$-лактамам процент резистентных штамов составлял от 76,9 \% до $100 \%$, к макролидам - от $4,7 \%$ до $100 \%$, к аминогликозидам - от $17,2 \%$ до $100 \%$, к фторхинолонам - от $6,3 \%$ до $100 \%$, к тетрациклинам - от $10 \%$ до 100\%. Полирезистентные штаммы (к гентамицину, енрофлоксацину, триметоприму) были выделены в Донецкой области. Наименьший процент резистентности наблюдался в Волынской области, где только одна Pseudomonas была резистентна к тетрациклину.

По пастереллам ситуация не менее тревожная, так как их устойчивость к $\beta$-лактамам составила от $21,1 \%$ (в Запорожской области) до 100 \% (Житомирская, Ивано-Франковская, Киевская и Черкасская области), к макролидам от 71,4\% (в Винницкой области) до $100 \%$ (в Черкасской области), к аминогликозидам - от 28,6 \% (в Винницкой области) до 100 \% (Житомирская и Черкасская область), к фторхинолонам и тетрациклинам - от $12,5 \%$ до $100 \%$. Полирезистентный штамм был выделен в Черкасской области, он был устойчив одновременно к 17 антибактериальным препаратам.

Заключение. Результаты исследований позволяют утверждать, что ситуация по резистентности возбудителей бактериальных заболеваний животных к антибактериальным препаратам в Украине вызывает беспокойство. Географические границы не могут повлиять на распространенность резистентных к антибиотикам микроорганизмов и зависят, в первую очередь, от того, какие антибактериальные препараты используются в животноводстве того или иного региона/ области.

С целью мониторинга тенденций резистентности к антибиотикам, необходимо наладить межведомственный обмен информацией между медико-санитарными и ветеринарным компетентными органами, рассмотреть возможность создания общегосударственной программы мониторинга по устойчивости к антибактериальным препаратам по конкретному перечню видов бактерий, особенно тех, которые передаются через пищевые продукты, антибактериальных препаратов, методов исследования.

Чтобы побороть эту нарастающую проблему следует обратить внимание на следующие моменты.

1. Необходимость применения антибиотиков сельскохозяйственным животным должна быть уменьшена за счет улучшения здоровья животных путем осуществления мер биологической безопасности, профилактики заболеваний (включая применение эффективных вакцин, пребиотиков и пробиотиков), создания удовлетворительных санитарно-гигиенических условий и использования эффективных методов управления. 
2. Применение антибиотиков в качестве стимуляторов роста должно быть исключено.

3. Антибиотики можно применять в случаях, когда они предназначены ветеринаром в терапевтических целях, а их использование должно основываться на результатах исследования чувствительности выделенных культур микроорганизмов к антибиотикам. Преимущество следует отдавать антибиотикам с узким спектром действия.

4. Антибиотики, признанные критически важными для медицины, особенно фторхинолоны и цефалоспорины третьего и четвертого поколений, должны применяться у животных только в случаях крайней необходимости.

\section{ЛИТЕРАТУРА}

1. Глобальная стратегия ВОЗ по сдерживанию устойчивости к противомикробным препаратам. - Женева, Всемирная организация здравоохранения, 2001.

2. Відкриття антибіотиків - початок нової епохи в медицині. - [Електронний ресурс]. - Режим доступа: http://www.likarka.ru/tse-tsikavo/vidkrittya-antibiotikiv-pochatoknovoji-epokhi-v-meditsini.

3. Забровская, А. В. Чувствительность к антимикробным препаратам микроорганизмов, выделенных от сельскохозяйственных животных и из продукции животноводства / А. В. Забровская // VetPharma. - 2012. - № 5. - C. 20-24.

4. Капитан, Г. Б. Антибиотикотерапия: мифы и реальность [Электронный ресурс] / Г. Б. Капитан // Национальный институт фтизиатрии и пульмонологии им. Ф. Г. Яновского. - Режим доступа: http://www.ifp.kiev.ua/doc/people/antibiotic.htm.

5. Методичні вказівки щодо визначення чутливості мікроорганізмів до антибактеріальних препаратів / [Т. О. Гаркавенко та ін.]. - К., ДНДІЛДВСЕ, 2014. - С. 19-24.

6. Фещенко, Ю. І. Антибіотикорезистентність мікроорганізмів. Стан проблеми та шляхи вирішення / Ю. І. Фещенко, М. І. Гуменюк, О. С. Денисов // Український хіміотерапевтичний журнал. - 2010. - № 1-2 (23). - C. 4-10.

7. Black, W. D. The use of antimicrobial drugs in agriculture. Canadian Journal of Physiology and Pharmacology, 1984, 62:1044-1048.

8. EUCAST disk diffusion antimicrobial susceptibility testing method summary. [Електронний ресурс] // European Committee on Antimicrobial Susceptibility Testing. - Режим доступу до журн.: - www.eucast.org.

9. Mellon, M., Benbrook, C., Benbrook, K. L. Hogging it: estimates of antimicrobial abuse in livestock. Cambridge, MA, Union of Concerned Scientists, 2001.

10. Opinion of the Economic and Social Committee on resistance to antibiotics as a threat to public health. Brussels, Economic and Social Committee of the European Union, 1998 (http://eescopinions.eesc.europa.eu/EESCopinionDocument.aspx?identifier=ceslanciennes_sect ionslenvilenvi471 \ces1118-1998_ac.doc\&language=EN, accessed 7 February 2011).

11. Routine and extended internal quality control for MIC determination and disk diffusion as recommended by EUCAST. [Електронний ресурс] // European Committee on Antimicrobial Susceptibility Testing. - Режим доступу до журн.: - www.eucast.org.

12. Sojka, W. J., Carnaghan, R. B. A. Escherichia coli infection in poultry. Research in Veterinary Science, 1961, 2:340-352.

13. Swann, M. M. et al. Report of the Joint Committee on the Use of Antibiotics in Animal Husbandry and Veterinary Medicine. London, Her Majesty's Stationery Office, 1969. 